\title{
A dimensão iluminista da reforma pombalina dos estudos: das primeiras letras à universidade*
}

Carlota Boto

Universidade de São Paulo, Faculdade de Educação

\author{
É o Método o primeiro requisito do Estudo, para, por \\ meio dele se poder adquirir um conhecimento profundo \\ e sólido das Ciências. Quem desconhece o Método não \\ pode ter ordem no Estudo. E quem estuda sem ordem, \\ adianta-se pouco na Estrada das Ciências, tropeça a \\ cada passo e perde um tempo infinito. \\ Compêndio, 1972, p. 245
}

\section{A secularização como um modo de ser mundo}

O Iluminismo foi um fenômeno intelectual que teve lugar na Europa em meados do século XVIII. Tinha por principal baliza a referência da crítica; compreendendo o mesmo conceito de crítica como o reconhecimento das possibilidades, mas também dos limites da capacidade humana de conhecer. Mais do que isso, os iluministas compreendiam que a instrução conduziria não apenas a um acréscimo de conhecimento no sujeito, mas também a um aprimoramento do indivíduo que se instrui. Movimento crítico do Absolutismo; crítico da sociedade estamental; dos consequentes privilégios da aristocracia e do clero; crítico, enfim, das instituições de uma ordem política considerada arcaica. Propunha-se refundar a nacionalidade; e, para tanto, havia de ser criado um novo pacto civil.

* O presente artigo foi originalmente elaborado com o título "O Iluminismo e as reformas pombalinas", a convite do Colóquio 250 anos de ensino público no Brasil, realizado em junho de 2009, na Faculdade de Educação da Universidade Federal de Minas Gerais.
Apostando no avanço do espírito humano e do conhecimento, no progresso dos povos e na caminhada do gênero humano rumo a um indefectível percurso de aprimoramento - a que chamava perfectibilidade-, o Iluminismo foi também um movimento de fé: fé na razão, no futuro, na flecha de um tempo, no comércio entre os homens e, finalmente, fé na educação. Edgar Morin (1988) admite ter sido a fé nessa racionalidade crítica que - transformada em mística quase religiosa - firmou no Ocidente, para o bem e para o mal, o universalismo do conceito de Humanidade. ${ }^{1}$ De todo modo, "o espírito racional era e é universal" (p. 85).

Uma das marcas do Iluminismo português foi sua dimensão religiosa, convivendo com a ideia de um Estado condutor dos assuntos temporais. Pode-se

${ }^{1}$ Edgar Morin dirá que há um antagonismo profundo nesse humanismo europeu, que se radicaliza no século das Luzes. As contradições manifestar-se-iam entre a crença na universalidade desse mesmo humanismo, a qual, por si mesma, "dissimula um europocentrismo dominador, e a sua potencialidade verdadeiramente universalizante, aberta a todos os indivíduos e a todas as culturas, que desmascara e critica o europocentrismo" (Morin, 1988, p. 101). 
dizer que "se toda a laicidade é uma secularização, nem toda a secularização é (ou foi) uma laicidade" (Catroga, 2006, p. 273). São conceitos com significados diversos. Como diz ainda Catroga, "o conceito de secularização passou a conotar a perda, nas sociedades modernas ocidentalizadas, da posição-chave que a religião institucionalizada ocupava na produção e na reprodução do elo social e na atribuição de sentido" (p. 62). A religião deixa de ser a viga mestra da cultura, sua pedra de toque, e passa a ser um recurso auxiliar. Já a laicidade supõe - de modo radical - "a institucionalização da diferença entre o espiritual e o temporal, o Estado e a sociedade civil, o indivíduo e o cidadão" (p. 273). A clivagem entre a instrução pública portuguesa e o modelo pedagógico arquitetado pelos planos da França revolucionária acontece aí. A escola pombalina não era conduzida pela utopia da emancipação.

O fenômeno da secularização é - este sim, como já se observou acima - um dos alicerces do Iluminismo e da modernidade. Junto da progressiva secularização das instituições, vinham os emblemas da racionalização, da "civilização de costumes" (Elias, 1993, 1994) e do que Weber (2000) qualificou de desencantamento do mundo.

Carlos Guilherme Mota (2006) define o homem da Ilustração como o "homem da Razão, da Lógica, da Experimentação, da Ciência, do Direito Natural. Era o pesquisador, cosmopolita, reformista, antiabsolutista" (p. 67). Fenômeno europeu no século XVIII, a secularização integra o movimento que separa a moralidade da religião, que marca os limites entre Estado e Igreja; “que determinará o mundo e o modo-de-ser-no-mundo do homem moderno. Por isso, uma interpretação do Iluminismo é, por essência, uma leitura da Secularização" (Pereira, 1990, p. 7).

Também Roberto Romano (2003) destaca o princípio da secularização inscrito no projeto das Luzes como elemento essencial para estruturar um imaginário que daria lugar a preceitos de universalidade, nos quais os signos da impessoalidade e da igualdade jurídica se tornassem as grandes ideias-força da cultura política moderna: "lei natural, razão, vontade geral, povo etc." (p. 22). Trata-se de um movimento no qual, progressivamente, por etapas, o Estado-Nação viria a "vassalizar" a Igreja (Morin, 1988, p. 45). Por isso, vale para o caso português, sob a égide de Pombal, a caracterização de Edgar Morin acerca da situação francesa do Antigo Regime: "a monarquia absoluta foi relativa" (idem, ibidem). Laerte Ramos de Carvalho destaca também o sentido de secularização impresso na reforma pombalina dos estudos menores. Diz o historiador:

\begin{abstract}
[...] seu objetivo superior foi criar a escola útil aos fins do Estado e, nesse sentido, ao invés de preconizarem uma política de difusão intensa e extensão do trabalho escolar, pretenderam os homem de Pombal organizar uma escola que, antes de servir aos interesses da fé, servisse aos imperativos da Coroa. (1978, p. 139)
\end{abstract}

Marques destaca que despotismo esclarecido foi a "fase tardia do absolutismo régio, muito mais em conexão com as grandes mudanças que a Europa sofreu no século XVIII do que com a única influência de uma atitude filosófica" (1984, p. 322). Maria Lúcia Garcia Pallares-Burke (2001) acredita que as principais medidas voltadas para a criação e organização de escolas de Estado no século XVIII europeu seriam oriundas, não tanto das ideias iluministas, mas, sobretudo, daqueles que a história chamou de "déspotas esclarecidos". Por sua iniciativa, foram adotadas políticas públicas dirigidas a "racionalizar e ilustrar seus Estados" (idem, p. 59). Para tanto, a historiadora dá o exemplo da introdução do "ensino compulsório e universal nos reinados de Frederico II da Prússia (1740-1786) e Maria Tereza da Áustria (1740-1780)" (idem, ibidem). O modelo de ensino arquitetado para ambos os reinos tinha como ponto comum o atendimento das necessidades do Estado quanto à formação de consensos. Nesse sentido, os principais valores veiculados pela escolarização - especialmente a primária - seriam diligência, obediência, sentimento de dever e presteza na interiorização de regras. Tratava-se - pode-se dizer - de um modelo voltado para a formação de súditos esclarecidos; mas não de cidadãos. Mesmo assim, Pallares-Burke se interroga: "como explicar que 
dois governos absolutistas, e não os mais progressistas regimes inglês e holandês, procurassem pôr em prática a educação do povo e, com isso, fossem coerentes com o princípio do ecumenismo racional que era defendido em teoria?" (idem, ibidem). Seja como for, esses monarcas orientavam-se inequivocamente por uma compreensão diversa acerca da potencialidade da educação na produção do controle social. Mas talvez os mesmos soberanos compreendessem que o desenvolvimento da escolarização teria algo a ver com a prosperidade dos povos.

Luzes, esclarecimento, Iluminismo ou despotismo esclarecido? Muitos já tentaram definir o Marquês de Pombal. Para nós, educadores brasileiros do princípio do século XXI, a certeza que temos é a de que, nos territórios que geriu, foi ele o criador da escola pública de Estado - precisamente há 250 anos.

O modelo de escola pública que Pombal gestou tinha-vale dizer - características próprias: tratava-se de um artefato organizador da força e da potência do Estado. Sem dúvida alguma, rascunhavam-se ali - como sublinha António Nóvoa (2005) - "as condições para o processo histórico de uma sociedade de base escolar" (p. 23). O Estado tomava para si a tarefa de selecionar, nomear e fiscalizar professores. O Estado controlaria as matérias a ser ensinadas. Mas não havia intuito de, por meio da educação, alterar a base político-social desse mesmo Estado. O projeto pombalino (e a Ilustração portuguesa que o embasou) não se inscreveu - como observa Catroga (2006, p. 360) - em nenhuma luta de libertação nacional. A veia regalista conduzia um processo de secularização das instituições e dos costumes. Tal percurso traduziu-se como a Modernidade possível para o mundo lusitano.

A escola estatal do mundo que Portugal perfilhava teve lugar a partir de 28 de junho de 1759 com o Alvará Régio que implementava a Reforma dos Estudos Menores. O protagonista da mesma reforma, personificando a lógica do despotismo esclarecido à portuguesa, é o Marquês de Pombal - que tinha por referenciais políticos alguns teóricos e pedagogos lusitanos: D. Luís da Cunha, António Nunes Ribeiro Sanches e Luís António Verney.
Todos eles compunham uma geração de estrangeirados; tanto porque viviam fora de Portugal quanto porque observavam a situação portuguesa com base em tal deslocamento do olhar (Andrade, 1980; Moncada, 1941). A ambiguidade profícua dessa situação de estrangeirado adviria da observação da realidade estrangeira por parte de alguém que tem no seu país de origem a referência. A comparação com outros países parecerá, nesse caso, irresistível e inevitável. Os estrangeirados portugueses do século XVIII preocupavam-se com o atraso cultural do país. Consideravam que a situação do seu Portugal contemporâneo era de decadência: perante os países mais avançados da Europa; à luz dos rumos tomados pela colonização; diante do poder que um dia o país acreditou possuir.

Muitos fatores explicam o poder do Ministro; a maior parte deles compreensível à luz de uma história comparada. Porém há sempre algo que diz respeito à especificidade nacional; àquilo que, do exterior, não é facilmente identificado. Aliás, além disso, na história, há o fator acaso; e talvez Oliveira Martins (1991) não estivesse errado quando disse que uma das causas do poder do Marquês decorreu da atuação que este tivera quando do terremoto que faria morrer em Lisboa de 10.000 a 15.000 pessoas.

Consta que, ao ser indagado pelo Rei sobre o que fazer diante da tragédia que fizera ruir mais da metade dos prédios de Lisboa, o então Ministro dos Assuntos Exteriores e da Guerra (desde 1750), Sebastião José de Carvalho e Melo, teria respondido: "enterre os mortos, feche os portos e cuide dos vivos". A partir daí, o Ministro teria conquistado definitivamente a confiança do Rei; que, no ano seguinte (1756), o nomearia Secretário de Estado dos Negócios do Reino de Portugal. O Rei, com esse ato, daria a Sebastião José de Carvalho e Melo - futuro Conde de Oeiras, em 1759, e Marquês de Pombal, em 1769 - estatura de primeiro ministro do reinado português. Como bem observa Kenneth Maxwell (1996, p.24), “foi o terremoto que deu a Pombal o impulso para o poder virtualmente absoluto que ele conservaria por mais de vinte e dois anos, até a morte do rei, em 1777”. 


\section{Dom Luís da Cunha e seu Testamento político: decadência, sangrias e alternativas}

Ao abordar a atuação de D. Luís da Cunha (16621749), a bibliografia costuma sublinhar sua atividade diplomática em Londres, onde teria sido nomeado embaixador. Ao olhar do exterior para seu país - dizem os historiadores -, Luís da Cunha acentuava a necessidade de se fortalecer o papel do rei. Além disso, preocupava-se com a dependência portuguesa perante a Grã-Bretanha, com as dificuldades comerciais enfrentadas pelo país, e, especialmente, com uma certa "fraqueza auto-imposta de Portugal no tocante à falta de população e de espírito de iniciativa" (Maxwell, 1996, p. 16). Como indica, sobre o tema, Carlos Guilherme Mota (2006, p. 39), o Testamento político de D. Luís da Cunha - escrito nos anos de 1740, um pouco antes da subida do príncipe D. José ao poderorienta o monarca sobre quem deveria ser escolhido como principal ministro do reino. Ele sugere mais de um nome, dentre os quais sublinha o de Sebastião José de Carvalho e Melo, "cujo gênio paciente, especulativo e ainda que sem vício, um pouco difuso, se acorda com o da nação" (Cunha, 1976, p. 27). Mota assinala que D. Luís da Cunha teria se destacado também por uma visão mercantilista inovadora para seu tempo, tendo sido, indubitavelmente, um dos idealizadores da modernização econômica do Reino: "seu discípulo, Pombal, tornar-se-ia a figura central dessa constelação da qual D. Luís era o mentor" (Mota, 2006, p. 47).

Luís da Cunha discorreria sobre "a lastimável situação de Portugal no concerto europeu" (idem, p. 35). Mota compreende que, "inspirador do marquês reformista" (idem, p. 38), D. Luís da Cunha foi a "expressão máxima do pensamento cosmopolita e reformista luso da primeira metade do século XVIII, antecipando a Ilustração portuguesa" (idem, ibidem). Inaugurava-se ali uma "reflexão crítica sobre os males de Portugal e os seus remédios" (idem, ibidem). Portugal era compreendido como um organismo doente, a quem se deveria observar os sintomas, os humores e a debilidade; de modo a buscar identificar "o conhecimento da causa do mal que o aflige: isto não só para remediar a sua queixa, mas para prevenir o de que pode estar ameaçado" (idem, p. 43).

A causa primordial da fragilidade portuguesa residiria na estreiteza dos limites de seu território. Tal debilidade era, ainda, acentuada quando se comparam "nossas forças à proporção das dos seus vizinhos" (idem, ibidem). Em virtude dessa irreparável fraqueza, Portugal se teria lançado ao encalço de outras terras; favorecido por uma situação geográfica que - esta sim - lhe era favorável: a vizinhança do mar. Porém, a aventura das navegações não teria sido capaz de conter o mau uso das terras do reino: terras incultas, proprietários que não cultivavam seus terrenos e, até mesmo, "porções de terras usurpadas ao comum das cidades, vilas e lugares" (idem, p. 61). As terras incultas por desinteresse dos donos ou dos rendeiros deveriam ser-lhes retiradas para ser entregues a pessoas que pudessem e quisessem cultivá-las (Falcon, 1982, p. 254).

D. Luís da Cunha desenvolve a tese de que as razões que levaram Portugal a se apequenar perante os demais países de Europa consistiram em um conjunto de fatores que ele caracterizou como sangrias.

A primeira sangria que destruía e despovoava o reino português residiria no conjunto de pessoas de ambos os sexos que procuravam os conventos. Tornando-se frades e freiras, renunciavam ao mundo, não procriavam, não trabalhavam para o país e não povoavam o reino com sua prole.

A segunda sangria que "não deixa de enfraquecer o corpo do Estado, e a que não acho remédio, é o socorro da gente que anualmente se manda para a Índia" (idem, p. 74). Eram especialmente marinheiros que, ao fazer isso, deixavam mulheres e filhos - mulheres que, não fosse isso, poderiam ter muitos outros filhos. O Brasil estava também incluído nessa segunda sangria: para lá iam todos os que - sem passaporte encantavam-se com a promessa das minas e o desejo de fazer nova vida.

A terceira sangria do Estado português viria dos atos da Inquisição relativamente àqueles que eram por causa dela - chamados cristãos-novos. Essa sangria D. Luís da Cunha caracteriza como "insensível 
e cruelíssima" (idem, p. 75). Diariamente saem de Portugal essas pessoas, que, em solo português, não teriam qualquer oportunidade. O reino, assim, era, também por isso, despovoado. Uma forma de extinguir esse problema seria dar aos judeus a possibilidade de viver sua religião - como, aliás, "se pratica entre todas as nações da Europa” (idem, p. 88). D. Luís da Cunha expressava sua conviç̧ão de que, quanto mais gente fosse perseguida, acusada e punida, maior seria o número de judeus travestidos de cristãos-novos. Além disso, quando cessassem as perseguições, deixaria de haver "tantos sacrílegos quantos, sendo no coração judeus, frequentam os santos sacramentos, para não serem descobertos" (idem, p. 91). Finalmente - sem as clivagens que retiram das pessoas oportunidades que seriam justas -, os judeus (convertidos então em cristãos-novos), caso pudessem assumir sua verdadeira identidade religiosa, permaneceriam no Reino, fazendo com que seu capital girasse em torno dos negócios portugueses; o que desenvolveria a economia nacional "e faria florescer o seu comércio" (idem, ibidem). A liberdade de religião e a confiança de que não teriam seus bens confiscados fariam com que os judeus contribuíssem para desenvolver e equilibrar o comércio português.

E o desequilíbrio comercial - preocupação com que Luís da Cunha finaliza o texto - pode ser compreendido como a quarta sangria que ceifava o vigor e a potência do reino português.

\section{Ribeiro Sanches e suas Cartas sobre a educação da mocidade}

António Nunes Ribeiro Sanches (1699-1782) era um médico que, cristão-novo, embora tenha iniciado seus estudos em Coimbra, cedo se transferiu para Salamanca, onde formou-se em medicina. Diz Rómulo de Carvalho (1986) que ele saiu do país aos 27 anos e nunca mais regressou. Exerceu a Medicina na Rússia, entre 1731 e 1747, tendo sido médico da Czarina. Na Rússia, ele dirigiu um hospital, desenvolveu investigações científicas e clinicou na Escola Militar de São Petersburgo. Quando soube que Pombal havia publicado o Alvará de 28 de junho de 1759, expulsando a Companhia de Jesus, Ribeiro Sanches teria se entusiasmado a redigir um trabalho sobre o tema da educação. Publicada em 1760, essa obra, sob o título Cartas sobre a educação da mocidade, constitui um importante opúsculo para se ter uma ideia do que foi, em matéria educativa, o Iluminismo no tempo e no território do Marquês de Pombal.

Ribeiro Sanches destacava que os privilégios e as imunidades das ordens privilegiadas teriam sido a causa da deturpação de costumes e da má educação portuguesa. A mocidade não era preparada para ser boa nem para ser útil à Pátria. Pelo contrário: o fidalgo era educado para tratar como escravos todos os subalternos - como se as pessoas do povo não fossem proprietárias de seus corpos e de sua honra. A fidalguia é ainda criticada porque acostumava mal as pessoas. Aqueles que desfrutavam do epíteto de fidalgos não poderiam, por exemplo, ser presos por dívidas. O resultado do privilégio era frontalmente contrário aos interesses do reino: "o senhor é dissipador, nem sabe o que tem, nem o que deve; perde toda a ideia de justiça, da ordem, da economia; pede emprestado com mando, maltrata e arruína a quem lhe recusa" (Sanches, s.d., p. 97). Além disso - prossegue o autor -, se pela religião cristã todos seriam iguais perante os mandamentos da Igreja, como justificar essas desigualdades de tratamento entre as pessoas? Como justificar as regalias? Contraditoriamente, o plano das Cartas - traçando um retrato do que seria adequado ao ensino português nos estudos menores e nos maiores - "dividia a mocidade em três grupos sociais cujo destino escolar nada tem a ver com as capacidades dos componentes dos grupos, mas apenas com a sua situação social. Os grupos são o povo, a classe média e a nobreza" (Carvalho, 1986, p. 439-440). A educação estaria, sob tal perspectiva, diretamente subordinada aos interesses econômicos, políticos, comerciais e até militares do Estado português.

As escolas - para Ribeiro Sanches - precisavam ser distribuídas estrategicamente. Existiriam apenas naqueles lugares onde fosse necessária a educação da juventude. Nesse sentido, o autor propunha a instau- 
ração de um tribunal voltado especificamente para as coisas do ensino; e, assim, "que em nenhuma aldeia, lugar ou vila onde não houvesse duzentos fogos não fosse permitido, a secular ou eclesiástico, ensinar por dinheiro ou de graça a ler ou a escrever" (Sanches, s.d., p. 129). Por qual motivo? Diz o autor que a instrução criaria no espírito uma certa altivez, inadequada para a maior parte das pessoas, especialmente para aquelas destinadas às lides do trabalho. $\mathrm{O}$ estudo, além do mais, exigia um esforço diametralmente contrário ao esforço físico; fazendo com que a juventude perdesse o vigor e a força: "aquela desenvoltura natural; porque a agitação, o movimento e a inconstância é própria da idade da meninice" (idem, ibidem). O excesso de estudo enfraqueceria o corpo, já que, na escola, os meninos ficam "assentados, sem bulir, tremendo e temendo" (idem, ibidem). Por causa de tudo isso, Ribeiro Sanches conclui que nem todos deveriam frequentar a escola: "não convém uma educação tão mole a quem há-de servir à república, de pés e de mãos, por toda a vida" (idem, ibidem). Para o povo miúdo, não convinha a escola. Ribeiro Sanches era iluminista; e o Iluminismo era também isso.

Para as escolas a serem abertas e controladas pelo Estado, Ribeiro Sanches sugere que - particularmente nas de primeiras letras -, em vez do aprendizado por catecismos religiosos, fosse elaborado catecismo de novo tipo - aquele voltado para ensinar às crianças "as obrigações com que nasceu” (Sanches, s.d., p. 133). Para tanto, as escolas deveriam providenciar "livrinhos impressos em português por onde os meninos aprendessem a ler, onde se incluíssem os princípios da vida civil de um modo tão claro que fosse a doutrina compreendida por aquela idade" (idem, ibidem). A isso o autor denomina "catecismo da vida civil" (idem, ibidem). Conhecimentos, valores e condutas ali impressos seriam ensinados às crianças "com castigos e com prêmios, acostumando aquela idade mais a obrar conforme a razão do que a discorrer" (idem, ibidem). Por meio do livro escolar, seriam instruídas quanto a comportamentos e ações para com os mais velhos, os colegas, a vida social. Pelo compêndio se haveria de compreender "que ninguém na prosperidade e na grande alegria se deve desvanecer nem ensoberbecer, porque somos nascidos para viver uma vida cerceada sempre pela alegria e pela tristeza; que nenhum bem é sem mistura de mal, nem nenhum mal sem mistura de bem" (idem, p. 135). Tudo isso - saberes e costumes poderia ser ensinado à meninice; o que, aliás, não era difícil, como demonstra a facilidade natural que qualquer criança apresenta em dominar rapidamente a forma oral de sua língua materna. ${ }^{2}$ Mas é fundamental que não nos esqueçamos que, para atingir a meninice, será necessário "o mestre lhe falar na língua e na frase que é própria àquela idade" (idem, ibidem).

Relativamente ao ensino das Universidades, Ribeiro Sanches centra-se no exemplo português da Universidade de Coimbra. Ali havia, na época, quatro faculdades: Direito Canônico, Jurisprudência, Teologia e Medicina. Porém, segundo o autor, todos os cursos eram defasados e obsoletos. Note-se que não havia sequer um curso de Filosofia - compreendendose esse estudo como uma pertença do território da Teologia. Tomando o caso do Direito Canônico e da Jurisprudência, Ribeiro Sanches assegura que as referências daquele modelo de ensino eram absolutamente insuficientes para "formar conselheiros de Estado, embaixadores, generais, almirantes, etc.” (Sanches, s.d., p. 159). E a razão de tal insuficiência residia no fato de estar a universidade sob a exclusiva alçada do clero.

Havia uma arquitetura do Estado que pressupunha pessoas para gerirem a organização do reino. Isso requereria planejamento, execução de metas, fiscalização e controle. Daí a necessidade, identificada por Ribeiro Sanches, de preparo desses profissionais especializados, que teriam cargos na administração do reino. A instrução das chamadas escolas maiores

2 "É admirável o juízo humano: na idade de três anos aprendeu um menino a sua língua - falar sem saber o que faz, com o nominativo, com o verbo no singular ou no plural, no tempo, no modo, etc. O que é tão difícil aos adultos que aprendem as línguas doutas ou estrangeiras, pode o menino aprender, no dia, de três ou quatro mestres sem confundir o que aprende" (Sanches, s.d., p. 135). 
teria a tarefa de instruir o sujeito em suas "obrigações de cristão e cidadão" (idem, p. 172). Para tanto, haveria o menino de aprender latim e grego, história e geografia, poesia

\section{[...] e que saiba escrever, ou na língua latina ou na sua, com elegância e propriedade: porque o Estado não somente tem necessidade de letrados, jurisconsultos e médicos, mas também de secretários, de notários públicos, de intenden- tes, de conselheiros e assessores nos tribunais ou colégios que devem governar a economia política e civil do reino. Tanto mais instruídos saírem estes estudantes das escolas referidas, tanto melhor exercitarão os cargos em que serão empregados. (idem, ibidem)}

Ribeiro Sanches propõe, então, com base nos requisitos profissionais acima assinalados, três tipos de escolas maiores, que deveriam, por um lado, preparar a mocidade nobre para o aprendizado das ciências e, por sua vez, os súditos para bem servirem a pátria. Diz Joaquim Ferreira (s.d., p. 60) que "essas escolas maiores ou Faculdades seriam de fundação régia, independentemente da anuência da Santa-Sé". Ribeiro Sanches, ao tratar dos estudos maiores, sugere, sob os critérios acima indicados, a classificação das ciências em três modalidades de escolas.

Na primeira escola, seriam aprendidos os assuntos da natureza humana, dos corpos, de suas combinações, a história natural, a botânica, a anatomia, a química, a metalurgia e a medicina. A segunda escola seria voltada para os saberes necessários ao "Estado político e civil para governar-se e a conservar-se" (Sanches, s.d., p. 158), de modo a assegurar a felicidade dos súditos. Aqui as matérias de estudo seriam "história universal, profana e sagrada; a filosofia moral, o direito das gentes, o direito civil, as leis pátrias; a economia civil, que se reduz ao governo interior de cada Estado" (idem, ibidem). Finalmente, haveria uma terceira escola, que abarcaria os assuntos da religião mas essa teria sua estrutura organizada pelos próprios eclesiásticos -, sobre a qual Sanches afirma: "não me pertence a mim indicar o que nelas se devia aprender" (idem, ibidem). Assim, as coisas da religião ficariam separadas das "ciências humanas" (idem, p. 159).

E como deveriam ser as aulas de tais escolas? Começar-se-ia pela observação, à semelhança da percepção que temos na vida cotidiana, quando prestamos atenção às coisas, às pessoas e a nós mesmos. Daí partia-se para a lição, que era o modo de ilustrar o entendimento à luz do legado dos que vieram antes - aquilo que as gerações anteriores "aprenderam e experimentaram, como se nos valêssemos das riquezas que ajuntaram nossos antepassados" (Sanches, s.d., p. 165). Em seguida, ocorreria o chamado ensino dos mestres; sempre por "viva-voz e não por postilas ${ }^{3}$ nem temas, explicando o que deve inculcar no ânimo dos discípulos, perguntando, orando às vezes, e arguindo, não por silogismos, mas em forma de diálogo" (idem, ibidem). A partir daí, o quarto movimento do ensino seria a conversação, mediante a qual se pode apreender aquilo que os outros sabem. Ouvimos e aprendemos quando partilhamos; ou, nos termos do texto, quando "imitamos sem nos apercebermos o judicioso que ouvimos e admiramos; e, com agrado e amor da sociedade, transformamos o nosso entendimento naquele com quem tratamos" (idem, ibidem). Finalmente, aconteceria o momento da meditação; uma reflexão ou atenção madura da alma voltada para todos os movimentos anteriormente feitos no percurso desse aprendizado.

Crítico do ensino doméstico, Ribeiro Sanches recomenda o estabelecimento, em Portugal, de uma Escola Militar, que seria, para a mocidade portuguesa, de muito maior proveito do que a profusão do que o autor nomeia "estabelecimentos literários" (Sanches,

${ }^{3}$ O Dicionário Contemporâneo da Lingua Portuguesa: feito sobre o plano de F. J. Caldas Aulete, em sua terceira edição, no volume II, define a palavra postila: "livro, caderno ou folhas em manuscrito, por onde os alunos de uma escola ou universidade estudam as lições - explanação, explicação, comentário (ordinariamente manuscrito) a qualquer texto, doutrina, tratado, etc. - lição que nas aulas de instrução primária, o professor dita e os discípulos escrevem para se aperfeiçoarem na ortografia" (Aulete, s.d., p. 760). 
s.d., p. 183). Essa Escola Real Portuguesa seria voltada para a formação da nobreza e da fidalguia; com o fito de "educar súditos amantes da pátria, obedientes às leis e ao seu rei, inteligentes para mandar e virtuosos para serem úteis a si e a todos com quem devem tratar" (idem, p. 184). Nesse estabelecimento, os meninos ingressariam entre doze ou quatorze anos. Segundo comenta Rogério Fernandes, essa Escola Militar ou Colégio dos Nobres foi pensada para ser um "colégio destinado à educação militar da nobreza, com a condição, no entanto, de se não esquecer que os filhos da nobreza receberiam nesse colégio uma educação polivalente, de tal sorte que poderiam desempenhar funções nos estratos superiores do aparelho do Estado" (1992, p. 80). ${ }^{4}$ Joaquim Ferreira (s.d., p. 65) destaca que "Ribeiro Sanches, propondo ao Marquês de Pombal a criação do Colégio dos Nobres, nutria a certeza de ofertar à sua pátria um núcleo de estadistas capazes de engrandecê-la". E o Marquês de Pombal talvez ouvindo seu conselheiro - funda em 7 de março de 1761 o Colégio dos Nobres. ${ }^{5}$

${ }^{4}$ Rogério Fernandes (1992) recorda que, voltando-se para as questões de organização do sistema escolar, Ribeiro Sanches já dialogava, de alguma maneira, com as primeiras medidas tomadas pelo Marquês de Pombal nos estudos menores. Há ressonância das ideias de Ribeiro Sanches também em várias iniciativas pombalinas, revelando o modo pelo qual ideias e ações circulavam e se entremeavam à época: "fundação do Real Colégio dos Nobres (1761), cuja abertura se efetua em 1766, e da Real Escola Náutica do Porto (1762); criação da Real Mesa Censória (1768), organismo que passa a superintender na atividade do Diretor dos Estudos; criação da Junta de Providência Literária (1770)" (Fernandes, 1992, p. 85)

5 "Embora não se conheçam documentos que nos autorizem a admitir qualquer afinidade entre o pensamento iluminista das cartas de Ribeiro Sanches e a orientação doutrinária do pombalismo, ainda que seja nos anos mais dramáticos da disputa com os jesuítas, o certo é que estas cartas não deixaram de ter repercussão, pois a criação do Colégio dos Nobres, por elas preconizada, logo encontrou o firme apoio do gabinete de Dom José I" (Carvalho, 1978, p. 91).
Ribeiro Sanches não hesita em indicar que "o primeiro e cotidiano ensino dessa escola deve ser a religião, para cumprirmos a obrigação de cristão" (Sanches, s.d., p. 193). Diferentemente, no entanto, da cultura clerical que imperava no período, a escola será administrada por mestres leigos - militares, “que ensinarão os exercícios corporais para fortificar o corpo, fazê-lo ágil e endurecido ao trabalho e à fadiga" (idem, ibidem).

Párocos e vigários restringir-se-iam a administrar sacramentos e a "instruir nos Domingos e dias de festa na religião; mas sem novenas, irmandades, confrarias e outras instituições, que não são essenciais à religião católica" (idem, ibidem). Verifica-se aqui um modelo de ensino que, embora não fosse laico, porque mantinha em seu cenário o universo religioso, era, sem dúvida, secularizado. Ou seja: quem mandava ali era o Estado. Esse era o plano. No projeto de Ribeiro Sanches, o controle da ação educativa não mais pertenceria à Igreja. Seria, antes de tudo, responsabilidade do Estado; inclusive porque a educação da mocidade era tida por estratégia para conservar e fortalecer a monarquia.

Outra providência recomendada por Ribeiro Sanches era a instituição de outro tipo de colégio: este voltado para formar meninas fidalgas. Sendo as mães as primeiras educadoras, tais escolas preparariam aquelas que, em primeiro lugar, teriam por missão a formação das novas gerações. Percebe-se, todavia, que a preocupação com a instrução das mulheres tem também o objetivo de ensinar a elas quais eram as coisas permitidas e as proibidas; o que deveria ser lido e o que estava proscrito. Nesse sentido,

Todas as primeiras ideias que temos provêm da criação que temos das mães, amas e aias; e se estas forem bem educadas nos conhecimentos da verdadeira religião, da vida civil e das nossas obrigações, reduzindo todo o ensino destas meninas fidalgas à geografia, à história sagrada e profana, e ao trabalho de mãos senhoril, que se emprega no risco, bordar, pintar e estofar, não perderiam tanto tempo em ler novelas amorosas, versos que nem todos são sagrados, e em 
outros passatempos onde o ânimo não só se dissipa, mas às vezes se corrompe. Mas o pior desta vida assim empregada é que se comunica aos filhos, aos irmãos e aos maridos. (Sanches, s.d., p. 190-191)

\section{O Verdadeiro método de estudar como projeto pedagógico de Verney}

Luís António Verney (1713-1792) era filho de pai francês e mãe portuguesa. Nasceu em Lisboa e foi aluno do Colégio Jesuítico de Santo Antão. Depois frequentou Artes e Teologia na Universidade de Évora. De lá, seguiu para a Itália, onde defendeu tese em Teologia (Cidade, 1985, p. 143). Defensor da filosofia moderna, que se assentava na fundamentação científica newtoniana, Verney postula a renovação dos estudos do reino português sob nova base - moderna. Para ele, isso supunha colocar de parte autores consagrados como Aristóteles, Galeno ou Hipócrates.

Luis António Verney, iluminista, foi - com D. Luís da Cunha e António Nunes Ribeiro Sanches referência teórica do pombalismo. Seu principal texto - Verdadeiro método de estudar - foi publicado antes na Itália do que em Portugal, onde logo depois também era impresso. Veio a público, pela primeira vez, em 1746, em Nápoles. Era um manual - escrito na forma de cartas - que contemplava variados aspectos da cultura: lógica, gramática, ortografia, metafísica etc. (Maxwell, 1996, p. 12). Em suas cartas, Verney, de alguma maneira, articula - por meio da crítica satírica - formas alternativas de se ensinar. Ele reputa como fundamental uma reforma que abrangesse, em Portugal, todo gênero de estudos: os menores (escolas de primeiras letras e colégios secundários) e os maiores (universidades).

Para o caso das escolas menores - especialmente no nível elementar - Verney declara que bastava examinar o interior das instituições de ensino para verificar que os mestres sobrecarregavam a memória das crianças "com coisas desnecessaríssimas" (Verney, s.d., p. 76). $\mathrm{O}$ excessivo apelo aos castigos derivaria, na vida escolar, dessa incapacidade de ensinar as coisas importantes e da incompetência para "facilitar o caminho para entendê-las" (idem, ibidem). Recomenda Verney que, em vez dos longos períodos em latim, "devia o mestre ensinar ao discípulo compor bem uma oração portuguesa breve - uma carta, um cumprimento, ou coisa semelhante" (idem, p. 78). O estudante faria isso com muito maior facilidade do que realizava suas composições em latim, já que agora "o faz em uma língua que sabe, na qual o mestre pode claramente mostrar-lhe os erros" (idem, ibidem). Verney advertia os contemporâneos para o que compreendia ser a realidade dos colégios; dos quais saíam homens que, além de não saber latim, não eram sequer capazes de redigir uma carta em português (idem, p. 79).

À luz dessa preocupação com os temas relativos ao ensino da língua, Verney critica a ignorância existente em matéria de ciência moderna, bem como o uso de tratados obsoletos sobre questões da física, o excessivo apego a um aristotelismo fora de época, e também o inaceitável recurso ao argumento de autoridade. Tudo isso paralisaria a razão - o que era, ainda, agravado pela excessiva valorização do verbalismo no ensino das ciências. Para Verney, em matéria de ciências, não interessa quem disse o que. Não interessa tanto como isso foi dito. O que parecia fundamental era verificar se a experiência comprova a veracidade da hipótese. Ao tratar agora do conhecimento das ciências, o autor encaminha-se para abarcar sua apreciação, não apenas dos estudos dessas matérias, mas dos modos de organização das chamadas escolas maiores - ou universidades.

Verney enfatiza a necessidade de se observar para saber. Compreender a natureza das coisas seria - para ele - observar bem e, para tanto, havia de se possuir um juízo claro: "observar muito, e bem, ou saber-se servir dos que o fizeram; e fundar os seus raciocínios em princípios evidentes, quais são os matemáticos" (Verney, s.d., p. 176). Sublinha sempre que apenas a experiência poderá conduzir ao conhecimento. Somente, pois, à luz da observação é que se poderá discorrer sobre qualquer coisa. "Nós não temos conhecimento imediato das naturezas; unicamente temos dois meios para o conseguir: observar as propriedades; e ver se, 
mediante alguma resolução, podemos chegar a conhecer os princípios de que se compõe esta ou aquela entidade física" (idem, p. 177). Mais do que isso, "não devemos querer que a natureza se componha segundo as nossas ideias; mas devemos acomodar as nossas ideias aos efeitos que observamos na natureza" (idem, ibidem). Finalmente, Verney argumenta que a ciência aristotélica - enredada em suas noções de matéria, forma e privação - não possui aparato conceitual para apreender, de fato, as realidades descortinadas pela ciência moderna. Tanto a lógica aristotélica quanto a razão escolástica eram absolutamente insuficientes para explicar os fenômenos da natureza.

Assim como fizera o médico Ribeiro Sanches, ${ }^{6}$ Verney - que não era médico - critica severamente os modos de se ensinar a medicina. Ambos - Ribeiro Sanches e Verney - " aconselhavam o adiantamento da filosofia natural (física e ciências naturais) e da clínica. Propugnavam o abandono da filosofia peripatética e da Medicina galeno-árabe" (Guerra, 1983, p. 283)". Além disso, os iluministas portugueses destacam "o primado das manifestações objetivas da doença, baseado no conhecimento das ciências exatas e naturais; o desenvolvimento do ensino e da prática da anatomia e da cirurgia" (idem, ibidem). Enfim, parecia imperioso substituir - como se dizia à época - a experiência da autoridade pela autoridade da experiência.

Verney identificava desdobramentos de uma ignorância a outra: o desconhecimento da física e da química era fundamento para a ausência de conhecimentos na medicina. A mesma estupidez conduzia ao desprezo pela anatomia. Desconhecendo-se a anatomia, erravam-se os diagnósticos e abusava-se de remédios errados. A cirurgia era um saber apenas prático, sem qualquer estatura teórica, já que esta requereria intrinsecamente conhecimento de anatomia.

${ }^{6}$ D. João V teria consultado Ribeiro Sanches sobre uma possível reforma dos estudos médicos (Guerra, 1983, p. 286). Ribeiro Sanches escreveu então, em 1761, um texto intitulado Método para aprender a estudar a Medicina - o qual procurei abordar em "O enciclopedismo de Ribeiro Sanches: pedagogia e medicina na confecção do Estado" (Boto, 1998).
Verney (s.d., p. 207) reconhece que o bom prático é, de fato, aquele que domina a "causa particular dessa determinada enfermidade" para podê-la curar. Porém o próprio saber prático - por isso mesmo - só seria enriquecido pelo conhecimento da anatomia. O corpo é uma máquina a ser esquadrinhada; e não se cura "às apalpadelas" (idem, p. 208).

A destreza necessária ao cirurgião é vista por Verney como absolutamente tributária de seu conhecimento anatômico, e ele dá exemplos de como o desconhecimento poderia ser funesto na prática cirúrgica: "conheci uma senhora a quem um clérigo deslocou duas costelas, querendo consertar-lhe uma; e ficou toda a sua vida com uma deformidade nas costas"(Verney, s.d., p. 215). Finalmente, para conclusão desse tópico, o texto assinala que, de todos os perigos, o pior seria o de recorrer àquelas pessoas que, dizendo possuir poderes mágicos, arrogam-se para si a virtude de curar. Era necessário tornar racional o aprendizado da medicina - e especialmente era urgente introduzir a matéria da anatomia com base no estudo de cadáveres humanos. Só assim seria superada a ignorância relativamente ao conhecimento do corpo humano, de suas enfermidades e de suas possibilidades de cura.

Luís António Verney parte de um pressuposto jusnaturalista para defender sua concepção de ética: "os homens nasceram todos livres, e todos são igualmente nobres" (s.d., p. 194). Os primeiros grupos sociais já teriam reconhecido a necessidade de se conferir racionalidade à vida em comum, além de ordem e obediência. Para isso, era indicado meditar sobre os costumes. As pessoas dependem umas das outras. Os mais virtuosos dentre os homens tendem a se destacar tanto em tempos de guerra quanto em tempos de paz. Sendo assim, costumam ser mais prestigiados do que os outros. Esse é o verdadeiro princípio da nobreza. Por aí, talvez erroneamente, acreditou-se que as pessoas transmitiam a seus filhos suas próprias virtudes.

Assim - conclui Verney - o que confere a nobreza ao sujeito não é o príncipe, mas a educação recebida: "se conduzirem esta criança a um país incógnito, e for criado por vilões, há-de ser vilão e não príncipe, e em 
tudo se parecerá com quem a criou" (s.d., p. 200). A pedra de toque do caráter e da verdadeira estirpe da alma seria, nesse sentido, a educação recebida; já que "os inteligentes sabem muito bem que o sangue do pai poderá comunicar ao filho alguma enfermidade hereditária, como gota, escorbuto, gálico, epilepsia etc.; mas de nenhum modo lhe comunica nem vícios nem virtudes" (idem, p. 202). Muitas vezes, pelo contrário, aqueles que são socialmente reputados como nobres frequentemente adquirem hábitos afetados, quando não pouco civis. Inclusive, "muitos, para fingirem uma nobreza mui elevada, até são descorteses: não cumprimentam quem os saúda; não respondem a quem lhes escreve; ou, se o fazem, é de uma maneira mais injuriosa que civil" (idem, p. 203).

Verney - aqui também como Ribeiro Sanches -é um defensor da instrução das mulheres. Serão mães de família; e, portanto, primeiras mestras. Ensinam as crianças a falar. Dirigem a economia das casas. Tudo isso, por si, já constituiria motivo para que elas fossem instruídas na cultura das letras. Além disso, o estudo formará seus costumes. Exatamente por não terem assunto com suas mulheres ignorantes (porque as julgam "tolas no trato") é que homens casados "vão a outras partes procurar divertimentos pouco inocentes" (Verney, s.d., p. 217). Nesse sentido, instruir as mulheres seria uma forma de obtenção de paz e de harmonia familiar. Além disso, cada donzela deveria "aprender a ter o seu livro de contas, em que assente a receita e despesa, porque sem isso não há casa regulada" (idem, p. 223). Muitas vezes as senhoras ficam viúvas e os bens são arruinados exatamente porque elas não possuem qualquer noção do "modo de conservar e aumentar as rendas de suas fazendas" (idem, ibidem). Por tudo isso, os trabalhos manuais e especialmente as prendas de salão ${ }^{7}$ seriam menos importantes do que

\footnotetext{
${ }^{7}$ Como diz Rómulo de Carvalho (1986, p. 417), aqui “o progressivismo de Verney não foi suficiente para vencer os preconceitos de classe". Ao dizer - quando avalia a futilidade do aprendizado das prendas de salão - que "nas senhoras grandes não é tão condenável aplicar-se a estes divertimentos inocentes, se o fazem com o fim de não ficarem ociosas (Verney, s.d., p. 227)", Verney distingue as
}

os conhecimentos rudimentares da leitura, da escrita e do cálculo. Desse modo, Verney propõe que o ensino feminino seja, tanto quanto possível, o mesmo que se deveria aplicar aos rapazes:

\begin{abstract}
O primeiro estudo das mães deve ensinar-lhes - por si ou, tendo possibilidade, por meio de outra pessoa capaz - os primeiros elementos da fé etc., explicando-lhes bem todas estas coisas, o que podem fazer desde a idade de cinco anos até os sete. Depois, ler e escrever português corretamente. Isto é o que rara mulher sabe fazer em Portugal. Não digo eu escrever corretamente, pois ainda não achei alguma que o fizesse; mas digo que pouquíssimas sabem ler e escrever; $\mathrm{e}$ muito menos fazer ambas as coisas corretamente. Ortografia e pontuação, nenhuma as conhece. As cartas das mulheres são escritas pelo estilo das bulas, sem vírgulas nem pontos; $\mathrm{e}$ algumas que os põem, pela maior parte, é fora do seu lugar. Este é um grande defeito, porque daqui nasce o não saber ler e, por consequência, o não entender as coisas. (Verney, s.d., p. 218)
\end{abstract}

Enfim, cobrindo praticamente todos os campos da instrução, o trabalho de Verney possibilitava uma avaliação panorâmica da situação do ensino português; por cuja leitura - em larga medida - Pombal se pautaria para "levar a efeito as suas reformas educativas" (Marques, 1984, p. 325).

\section{A escola pública traçada pelo Marquês de Pombal}

Quando sobe ao trono D. José I, em 1750, Sebastião José de Carvalho e Melo toma posse como ministro da Secretaria do Exterior e da Guerra. Ele trazia consigo a experiência diplomática e o que observara no exterior. Convivera durante anos com uma "comunidade de expatriados portugueses" (Maxwell, 1996, p. 10); os quais, na grande maioria das vezes,

pessoas nobres das outras. Essa contradição é típica dos autores iluministas; e o Iluminismo português não fugiria à regra. 
tinham deixado o país por se sentirem perseguidos ou tolhidos pela ação inquisitorial. Mas havia outro aspecto também fundamental: "as preocupações de Pombal também refletiam as de uma geração de funcionários públicos e diplomatas portugueses que haviam meditado muito sobre a organização imperial e as técnicas mercantilistas" (idem, ibidem). O padrão econômico mercantilista - e não ainda a economia de mercado - era compreendido pelos contemporâneos como o grande responsável pelo vigor político e pela riqueza econômica dos países centrais da Europa.

Laerte Ramos de Carvalho (1978) consagrou no Brasil a ideia de que teria havido ao menos duas reformas pombalinas da instrução pública, posto que vincula o ano de 1759 à reforma dos estudos menores e o ano de 1772 à reforma dos estudos maiores (ou da Universidade). Mas, à luz da interpretação de António Nóvoa (1987), Ruth M. Chittó Gauer (2001, 2004) e Tereza Fachada Levy Cardoso (2002), seria mais adequado compreendermos a existência de dois (ou mais) momentos de uma mesma reforma dos estudos; até porque as medidas implementadas relativamente aos estudos menores continuaram a ser elaboradas até a década de 1770 - e, do mesmo modo, algumas diretrizes relativas aos estudos maiores são anteriores.

Pode-se dizer que a reforma dos estudos gestada e executada por Pombal, em suas diferentes etapas, revolucionou a estrutura do ensino português. Fechou os colégios da Companhia de Jesus. Expulsou os jesuítas do Reino e de seus domínios - sob pretexto de que eles teriam participado de alguma maneira de um suposto atentado contra o rei. Confiscou seus bens. Muitos membros da Companhia foram deportados.

Por Alvará de 28 de junho de 1759, o futuro Marquês de Pombal reestruturou os chamados estudos menores. Criou-se, a partir dali, a acepção de aulas régias, compreendendo tanto as classes de primeiras letras quanto as classes de humanidades - daquilo que, posteriormente, se caracterizará como ensino secundário. Assinala Tereza Fachada Levy Cardoso (2004) que "a palavra régio tem um caráter ambíguo, porque, ao mesmo tempo em que remete à figura do monarca, reiterando uma tradição absolutista, que persiste período afora, representa também o avanço que o termo traz, pela contraposição à tradição de ensino por parte da Igreja” (p. 182). Eram, em sua grande maioria, classes de primeiras letras, incluindo o ensino da leitura, da escrita, da aritmética, do catecismo e dos preceitos da civilidade; mas havia também classes de latim, grego, hebreu e retórica (Marques, 1984, p. 337). Em todas elas, era proibido aos mestres e professores valerem-se dos livros e materiais de ensino utilizados pelos jesuítas. ${ }^{8}$

O Alvará de 28 de junho de 1759 parte da constatação de que existiria uma decadência em todos os campos dos estudos do Reino. Tal decadência era atribuída ao "escuro e fastidioso método" (in Almeida, 2000, p. 32) que os padres jesuítas introduziram nos colégios sob sua responsabilidade. $\mathrm{O}$ projeto da Reforma era, então, o de reaver o que Pombal denomina método antigo: "reduzido aos termos símplices, claros e de maior facilidade que se pratica atualmente nas nações mais polidas da Europa" (idem, ibidem). Haveria, pelo plano pombalino, um diretor dos estudos responsável por "fazer observar tudo o que se contém neste alvará e sendo-lhe todos os professores subordinados" (idem, ibidem). Esse

${ }^{8}$ Thaís Nívia de Lima e Fonseca (2006, p. 3709) sublinha que, para o caso da Capitania de Minas Gerais, "até que fossem implantadas as reformas na educação durante a administração do Marquês de Pombal, no governo de Dom José I, foi pouco visível a institucionalização da instrução elementar, na Capitania, já que não houve aqui a presença dos estabelecimentos educacionais jesuítas ou de qualquer ordem religiosa. Mesmo considerando as determinações constantes nas Ordenações do Reino, as ações no sentido de promover o ensino das primeiras letras ou o ensino secundário estavam, em geral, restritas aos particulares. A partir das reformas pombalinas e principalmente depois da criação das aulas régias, tornaram-se mais freqüentes as referências a esse tipo de educação na documentação administrativa. Foram recorrentes os ofícios enviados pelas Câmaras das vilas mineiras ao rei, solicitando a instalação de aulas, associando a necessidade da educação como instrumento de civilização, o que significa reforçar a formação moral, cívica e religiosa da população". 
diretor dos estudos, auxiliado por comissários ${ }^{9}$ que inspecionariam as escolas, deveria verificar o que faziam os professores, o que deixavam de fazer, além de "adverti-los e corrigi-los" (idem, ibidem), quando isso se fizesse necessário. Eram subordinados do diretor dos estudos todos os professores das escolas menores (Gomes, 1984, p. 9). Por isso, caberia a ele controlar os progressos dos alunos.

O projeto previa também que o diretor deveria ter "todo o cuidado em extirpar as controvérsias e de fazer com que haja entre eles (professores) uma perfeita paz e uma constante uniformidade de doutrina, de sorte que todos conspirem para o progresso de sua profissão e aproveitamento de seus discípulos" (Alvará, 2000, p. 32). Não deixa de ser revelador o fato de o Alvará de 1759 se referir ao ofício do magistério como profissão (Mendonça, 2005). O Alvará de Pombal indicava também as matérias que deveriam constituir as aulas régias; e, além disso, prescrevia quando e onde elas deveriam ser abertas. Chegava a recomendar livros para uso das escolas, de modo que fossem escolhidos compêndios alternativos àqueles utilizados pelos colégios jesuíticos. As aulas régias seriam abertas a todos, sem distinções de classe.

Quanto à reforma dos estudos maiores ou universitários - já destacava Rogério Fernandes (1992) -, ela teria sido deflagrada quando "a Junta da Providência Literária, a que presidiam o Cardeal da Cunha e o próprio Marquês de Pombal, elaborou em 1771 o Compêndio Histórico do Estado da Universidade de Coimbra" (Compêndio, 1972, p. 88). O referido documento oferece um preciso diagnóstico do que teriam sido os "estragos" realizados pela Companhia de Jesus nos estudos portugueses; especialmente nos estudos universitários.

${ }^{9}$ Como consta da obra de Laerte Ramos de Carvalho (1978, p. 116), os Comissários eram designados, nos diferentes lugares do Reino e de seus domínios, "para fazer o levantamento do número de professores existentes, tirando informação sobre sua vida e costumes, a fim de levar ao conhecimento do diretor geral dos estudos ampla notícia do estado em que se achavam as escolas em cada localidade".
A crítica severa do Compendio Historico do Estado da Universidade de Coimbra à Companhia de Jesus vem expressa na própria continuidade do texto que dá título ao documento: "no tempo da invasão dos denominados jesuítas e dos estragos feitos nas sciencias e nos professores e directores que a regiam pelas maquinações, e publicações dos novos estatutos por elles fabricados" (Compêndio, 1972). Suprimir os vestígios da Companhia de Jesus significava, à época, substituí-la à altura. Em primeiro lugar, desconstruir o suposto atraso; em seguida, formular uma alternativa. Quando foi feita a reforma da universidade, "aos novos professores catedráticos de Coimbra e Évora foi concedido o uso de residências dos jesuítas expulsos" (Maxwell, 1996, p. 205).

Ainda a propósito da estrutura do currículo, uma das censuras explicitadas no Compêndio pombalino dizia respeito ao fato de as escolas maiores - bem como todos os colégios controlados pelos jesuítas limitarem o estudo da moral ao conhecimento da moral aristotélica. A Ética de Aristóteles era, segundo consta do Compêndio, adotada como obra "para se ler nas escolas da Universidade de Coimbra; para se difundir nas Aulas de todos esses Reinos; e para constituírem nela o venenoso charco, donde saíram as mortíferas inundações" (Compêndio, 1972, p. 204). O argumento aqui é cristão. A obra do filósofo grego do século IV a.C. é considerada ímpia, ateia, prejudicial e indigna, por não ser regida pelos preceitos do cristianismo. Curiosamente, a denúncia do Compêndio repudia os estatutos jesuíticos vigentes na Universidade de Coimbra em virtude de uma defesa religiosa: a moral cristã. Aí está uma das tantas contradições do discurso iluminado do século XVIII.

O Compêndio é também severo ao denunciar o atraso dos métodos com que se ensinava em Coimbra. No caso dos cursos jurídicos, por exemplo, as aulas eram sempre uniformemente organizadas à luz do que o documento chama de "método analítico" (Compêndio, 1972, p. 262). O método analítico corresponderia a aulas centradas em comentários de textos considerados clássicos. Muitas vezes os professores ficavam presos a questiúnculas, fazendo longas digressões sobre 
uma só lei ou capítulo (idem, ibidem); mas que era tido como aquele que contemplaria a questão central e própria do texto. Essas lições analíticas" (idem, ibidem) eram explicações dadas sempre do mesmo modo, todos os anos, invariavelmente pelo mesmo professor, fazendo com que, no transcurso de sua vida universitária, o estudante travasse contato com pouquíssimos "textos e doutrinas; e ainda elas sem a conexão e dedução, que mais que tudo concorrem para elas bem se perceberem, e se imprimirem melhor na memória" (idem, ibidem).

Lia-se pouco; ouvia-se e copiava-se muito. Os lentes da universidade expunham, amiúde, "somente algumas leis e capítulos avulsos, cujas conclusões principais e doutrinas a elas pertencentes, e que nos mesmos textos se tratam, não podem bastar para a necessária instrução dos ouvintes" (Compêndio, 1972, p. 262-263). Por causa disso, os estudantes enfadavamse das aulas, muitas vezes deixavam a universidade "sem terem chegado a aprender, e nem ainda a ouvir as principais Regras e Primeiros Princípios de todas as matérias do Direito" (idem, p. 263) - como usualmente acontecia. Além disso, os comentários dos professores tornavam-se postilas, que "para as mesmas lições se ditavam" (idem, ibidem). E os alunos não estudavam pelos textos, mas pelas postilas. Tudo isso era feito sem qualquer domínio do que o Compêndio qualifica por “impreteríveis subsídios da interpretação genuína dos Textos" (idem, ibidem). Nada disso seria tão descabido - complementa o documento - caso esse referido "método analítico" fosse seguido do estudo sintético dos princípios e da doutrina do direito. Os estudantes precisariam aprender não apenas a interpretar corretamente as leis e os cânones, mas, se fossem "mais textuais, seriam mais hábeis para entenderem bem os textos; saberiam deduzir deles as suas verdadeiras conclusões" (idem, p. 264).

No estudo da medicina, a situação não era melhor. A ineficácia dos estudos preparatórios do curso de medicina também era um tópico bastante destacado no Compêndio pombalino. Formava-se em medicina sem ser preparado para a prática médica; sem sequer haver aprendido anatomia; sem que o sujeito houvesse assistido a cirurgias. Enfim, a formação dos médicos era completamente alheia à prática do ofício médico. Não se ocupava de observar o que médicos faziam com pessoas que adoeciam. Com a reforma do curso de medicina, Pombal dava concretude às sugestões que lhe haviam sido feitas por parte da geração de estrangeirados com quem conviveu. $\mathrm{O}$ ponto de partida da reforma do curso de medicina era o seguinte: "a autoridade, comparada com a experiência e com a demonstração racional, de nada vale" (Guerra, 1983, p. 293). O substrato da reforma será, portanto, o de considerar as grandes descobertas que modificavam o olhar da compreensão biológica - como, por exemplo, a descoberta de Harvey de que o sangue circula no corpo.

$\mathrm{Na}$ descrição feita das aulas ministradas para o curso de medicina, o Compêndio reitera aquele binômio típico, das lições e das disputas; estas últimas transformando-se, muitas vezes, em brigas ruidosas especialmente em ocasião de exames. A descrição fala por si mesma:

\begin{abstract}
A Aula da Medicina oferecia, então, um espetáculo notável, ao qual concorriam os Estudantes das mais Faculdades para se divertirem. Enfurecia-se o Presidente; gritavam os Arguentes; acendia-se o Defendente; todos queriam ter razão; e, como estavam dela distantes, nenhum sossegava, todos clamavam; e só vencia quem era mais destro e sutil em lançar palavras picantes. O Defendente saía com tudo aprovado, podia ser promovido à honra dos Graus Acadêmicos, e depois ir exercitar livremente a Medicina em prejuízo comum de todo este Reino. (Compêndio, 1972, p. 340)
\end{abstract}

Uma das principais dificuldades assinaladas pelo Compêndio referia-se à ausência de uma "ordem certa no ensino das matérias" (Compêndio, 1972, p. 330). Assim, "alguns aprendiam os Aforismos de Hipócrates no terceiro ano; e outros no quinto, conforme as matérias que o Lente ensinava quando eles principiavam seus estudos" (idem, ibidem).

Depois que deixavam a faculdade, a prática dos que se haviam formado em medicina pela Universidade de Coimbra era simplesmente a de "purgar, sangrar, etc.; sem saber as ocasiões oportunas em que 
deviam aplicar esses remédios" (idem, p. 342). Por não se terem habituado à observação médica, não eram capazes de conhecer as enfermidades; e, pela mesma razão, não sabiam prescrever remédios. Enfim, não sabiam curar. Por isso, toda gente achava que poderia fazer as vezes de médico.

\begin{abstract}
Tal era o estudo público da Medicina e tais os médicos que dele saíam. E que diremos da inumerável cópia de Cirurgiões, de Boticários, de Barbeiros, de Charlatões, de Segredistas, de Mezinheiros, de Impostores e até de mulheres Curadeiras, que, pelas Cidades, pelas Vilas, pelos Lugares e Campos se metiam a praticar a Medicina; e conseguiam a fortuna de serem atendidos e chamados até que a triste experiência de muitas mortes, de que eram réus, os fizesse ser desprezados? Teríamos aqui um larguíssimo campo para discorrer, e fazer ver quanto essa praga infeccionou o Estado. (Compêndio, 1972, p. 342-343)
\end{abstract}

O Compêndio assinala com veemência a necessidade de se introduzir a prática de dissecação de cadáveres humanos no curso de medicina da universidade. Só isso permitirá que os discípulos “aprendam a conhecer a estrutura, a configuração, a conexão de qualquer parte do corpo humano com outras partes" (Compêndio, 1972, p. 326).

Enfim, recuperar o atraso português era interagir com a transformação do estado das coisas em áreas consideradas estratégicas. Assim eram a educação (tanto os estudos menores quanto os maiores), a justiça e a medicina. Daí o privilégio dado pelo Compêndio tanto à formação jurídica quanto ao ensino da medicina. Reformar os estudos universitários - bem como reformar a instrução de primeiras letras e secundária - era o passaporte para a Reforma do Estado; um Estado que se pretendia incluído em seu tempo - competitivo e potente.

\section{Considerações finais: 250 anos depois; o legado dessa escola rastreada}

"Um país como os outros, a contas nunca certas com o tempo" (Lourenço, 1999, p. 109). Poderíamos emprestar a bela frase de Eduardo Lourenço para nos referirmos a esse Portugal do final do século XVIII. Diz Maxwell (1996, p. 104) que foram três os objetivos principais da ação pombalina em matéria de ensino: "trazer a educação para o controle do Estado, secularizar a educação e padronizar o currículo”. De fato, temos aqui uma síntese do que fizera o Marquês. Mas havia nisso uma preocupação com a demarcação das fronteiras. Nesse sentido, a expulsão dos jesuítas também era uma necessidade imperiosa do Estado português. Por causa da ação jesuítica, os indígenas brasileiros resistiam a "submeter-se à autoridade portuguesa, que eles viam como inimiga" (idem, p. 54). Pombal desejava a miscigenação para estabelecer o povoamento brasileiro, sem que, para tanto, ocorresse uma grande emigração dos portugueses. Era preciso, por todas as razões, retirar os jesuítas do controle das terras e das nações indígenas. Era necessário traçar a fronteira brasileira. O Estado necessitava disso. A coesão do Brasil significava naquele momento a força de Portugal.

Os oráculos do Marquês de Pombal - como já foram chamados os autores aqui estudados (Guerra, 1983, p. 287) - haviam alertado os contemporâneos sobre a fragilidade histórica do Estado português; sobre a necessidade de se estabelecer um plano mediante o qual o controle dos assuntos da instrução passasse de mãos religiosas para a tutela do Estado; sobre a urgência de, nesse mesmo sentido, reformarem-se os cursos universitários, que preparariam os funcionários do Reino. Tratava-se de pensar em um novo modo de gerir a justiça; tratava-se de fazer com que as pessoas vivessem mais - e, vivendo mais, pudessem se tornar hábeis para aprender coisas úteis. Tratava-se, sobretudo, de formar no território e nas colônias um modo de ser Portugal que fosse mais avançado, mais racional, mais moderno (Gauer, 1996, 2001).

Finalmente, é preciso compreender que Iluminismo não houve um só: foram vários. Há o Iluminismo da racionalidade e do progresso; mas há aquele que acentua a decadência nacional; aquele temeroso do atraso... O Iluminismo português - racionalizador, centralizador, secularizador - não era laico; e não era demasiadamente adepto da "extensão das liberdades 
individuais" (Maxwell, 1996, p. 170). Mesmo assim, a ação do Estado pombalino, em consonância com o pensamento iluminista português, foi além e trouxe medidas que não apenas favoreceram a laicidade ao reforçar o poder do Estado na ação política e no controle público - como promoveram também uma via emancipatória que ficaria clara no liberalismo português do século XIX e nas lutas por libertação nacional que aconteciam no Brasil daqueles tempos. $\mathrm{O}$ Iluminismo é constituído de luzes e sombras (PallaresBurke, 2001, p. 53-54). Mas em Portugal - como também aconteceria depois na França - a ação política radicalizou o pensamento iluminista que a precedeu.

Como ressaltou José Vicente Serrão (1989, p. 12), o pombalismo chega a ser maior do que o próprio Pombal. Tratava-se, no limite, de um projeto de gestão; empreendido, portanto, "por um conjunto de homens e de entidades institucionais, unidos numa espécie de rede de solidariedades políticas e pessoais, que tinha por centro a figura do Marquês de Pombal”. Para o autor, o pombalismo significou a construção do moderno Estado português - com uma clara vertente intervencionista; tida como imprescindível em decorrência da debilitação sofrida por Portugal nos anos que antecederam o reinado de D. José, e que haviam presenciado "a desorganização dos serviços administrativos, o aumento da corrupção, a proliferação de facções intestinas, uma grande indefinição de competências" (idem, p. 13). O pombalismo - à luz das ideias iluministas que lhe precederam - dignificou, em contrapartida, o estatuto de "funcionários públicos"como "parte integrante duma entidade institucional ampla: o Estado" (idem, p. 16).

Para concluir, creio que é preciso tomar cuidado com um aspecto. Pombal criou para si uma posteridade antecipada. Foi capaz de produzir representações, de fomentar uma autoimagem que indicasse ao futuro os significados desejados de sua biografia - e muito especialmente de sua dimensão política. Porém, como recorda Falcon (1982, p. 361), é preciso que se tenha clareza de que nem sempre coincidem as práticas de uma política ilustrada e as representações que tinham sobre elas os próprios protagonistas:

\begin{abstract}
A imagem que o ministro faz de si mesmo e do seu governo, a consciência que revela do poder real e dos deveres e atribuições dos ministros e secretários de Estado, seu universo mental, em suma, não têm nada em comum com a filosofia do "despotismo ilustrado".
\end{abstract}

Pombal foi moderno, até onde era possível a Portugal daquele tempo ser. Foi a consciência-possivel (Goldman, 1972) de uma geração de estrangeirados. Foi iluminista; mas foi, acima de tudo, homem de ação. Pelo discurso, mas especialmente pelos atos, ele, de fato - pode-se dizer -, enterrou os mortos e cuidou dos vivos. Não se compreenderá a lógica do ensino público brasileiro sem que essa história seja muito bem rastreada - uma história de 250 anos atrás...

\section{Referências bibliográficas}

ALVARÁ de 28 de junho de 1759. In: ALMEIDA, José Ricardo Pires. Instrução pública no Brasil (1500-1889): história e legislação. 2. ed. rev. São Paulo: Educ, 2000. p. 31-34.

ALVARÁ de 11 de janeiro de 1760. In: ALMEIDA, José Ricardo Pires. Instrução pública no Brasil (1500-1889): história e legislação. 2. ed. rev. São Paulo: Educ, 2000. p. 35-36.

ALMEIDA, José Ricardo Pires. Instrução pública no Brasil (15001889): história e legislação. 2. ed. rev. São Paulo: Educ, 2000.

ANDRADE, António Alberto Banha de. Verney e a projecção de sua obra. Lisboa: Instituto de Cultura Portuguesa/Ministério da Educação e da Ciência, 1980.

AULETE, Francisco J. Caldas. Dicionário contemporâneo da língua portuguesa: feito sobre o plano de F. J. Caldas Aulete v. II, 3. ed. Lisboa: Ed. Lisboa; Parceria António Maria Pereira, [s.d.]

BOTO, Carlota. Iluminismo e educação em Portugal: o legado do século XVIII ao XIX. Revista da Faculdade de Educação, Universidade de São Paulo, v.22, n. 1, p. 169-191, 1996.

O enciclopedismo de Ribeiro Sanches: pedagogia e medicina na confecção do Estado. História da Educação, Pelotas, Editora da UFPEL, v.2, n. 4, p. 107-117, set. 1998.

CARDOSO, Tereza Fachada Levy. As luzes da educação: fundamentos, raízes históricas e práticas das aulas régias no Rio de Janeiro (1759-1834). Bragança Paulista: EDUSF, 2002. 
. As aulas régias no Brasil. In: STEPHANOU, M.; BASTOS, M. H. C. (Orgs.). Histórias e memórias da educação no Brasil. Petrópolis: Vozes, 2004. p. 179-191.

CARVALHO, Laerte Ramos de. As reformas pombalinas da instrução pública. São Paulo: Saraiva/EDUSP, 1978.

CARVALHO, Rómulo de. História do ensino em Portugal: desde a fundação da nacionalidade até o fim do regime de Salazar-Caetano. Lisboa: Fundação Calouste Gulbenkian, 1986.

CATROGA, Fernando. Caminhos do fim da história. Coimbra: Quarteto, 2003.

. Entre deuses e césares: secularização, laicidade e religião civil. Coimbra: Almedina, 2006.

CIDADE, Hernâni. Portugal histórico-cultural. Lisboa: Presença, 1985.

COMPÊNDIO histórico do estado da Universidade de Coimbra (1771). Coimbra: Por Ordem da Universidade, 1972.

CUNHA, Luís da. Testamento politico, ou carta escrita pelo grande D. Luíz da Cunha ao Senhor Rei D. José antes do seu governo. São Paulo: Alfa-Ômega, 1976.

ELIAS, N. O processo civilizador: uma história dos costumes - v. 1. Rio de Janeiro: Zahar, 1993.

O processo civilizador: formação do Estado e civilização - v. 2. 2. ed. Rio de Janeiro: Zahar, 1994.

FALCON, Francisco José Calazans. A época pombalina; política econômica e monarquia ilustrada. São Paulo: Ática, 1982.

FERNANDES, Rogério. O pensamento pedagógico em Portugal. 2 ed. Lisboa: Instituto de Cultura e Língua Portuguesa/Ministério da Educação, 1992.

FERREIRA, Joaquim. Prefácio. In: SANCHES, A. N. Ribeiro. Cartas sobre a educação da mocidade. Porto: Editorial Domingos Barreira, [s.d.]. p. 7-85.

FONSECA, Thaís Nívia de Lima e. Discurso político e práticas educativas no Brasil do século XVIII. 2006. Disponível em: $<$ www2.faced.ufu.br/colubhe06/anais/arquivos/331ThaisNiviaLi maFonseca.pdf. 2006>. p. 3702-3711. Acesso em: 14 jun. 2009. . Instrução e assistência na Capitania de Minas Gerais: as ações das câmaras às escolas para meninos pobres (1750-1814). Revista Brasileira de Educação, v.13, p. 535-544, 2008.

GAUER, Ruth M. Chittó. A modernidade portuguesa e a reforma pombalina de 1772. Porto Alegre: Edipucrs, 1996.

. A construção do Estado-Nação no Brasil: a contribuição dos egressos de Coimbra. Curitiba: Juruá, 2001.
O pensamento iluminista português e a influência na formação da intelectualidade brasileira. In: STEPHANOU, Maria; BASTOS, Maria Helena Câmara (Orgs.). Histórias e memórias da educação no Brasil - v. 1: séculos XVI-XVIII. Petrópolis: Vozes, 2004, p.146-157.

GOLDMAN, L. Ciências humanas e filosofia. São Paulo: Difusão Europeia do Livro, 1972.

GOMES, Joaquim Ferreira. Estudos de história e de pedagogia. Coimbra: Livraria Almedina, 1984.

GUERRA, Miller. A reforma pombalina dos estudos médicos. In: Como interpretar Pombal? Lisboa/Porto: Brotéria, 1983. p. $277-295$.

LOURENÇO, Eduardo. A nau de Ícaro. 2. ed. Lisboa: Gradiva, 1999.

MARQUES, A. H. de Oliveira. História de Portugal-v.II. Lisboa: Palas Editores, 1984.

MARTINS, Oliveira. História de Portugal. Lisboa: Guimarães Editores, 1991.

MAXWELL, Kenneth. Marquês de Pombal: paradoxo do Iluminismo. Rio de Janeiro: Paz e Terra, 1996.

MENDONÇA, Ana Waleska P. C. A reforma pombalina dos estudos secundários e seu impacto no processo de profissionalização do professor. Educação, Universidade Federal de Santa Maria/RS, v.30, n. 2, p. 27-41, 2005.

MONCADA, Luís Cabral. Um iluminista português no século XVIII: Luiz Antonio Verney. Coimbra: Arménio Amador Editor, 1941.

MORIN, Edgar. Pensar a Europa. Mira-Sintra: Europa-América, 1988.

MOTA, Carlos Guilherme. Os juristas na formação do EstadoNação brasileiro (século XVI a 1850) - v.I. São Paulo: Quartier Latin, 2006 (Coleção Juristas Brasileiros).

NÓVOA, António. Le temps des professeurs - v.I. Lisboa: INIC, 1987.

Evidentemente: história da educação. Portugal: Asa, 2005.

PALLARES-BURKE, Maria Lúcia Garcia. Educação das massas: uma sombra no Século das Luzes. In: VIDAL, D.; HILSDORF, M. L. S. (Orgs.). Tópicas em história da educação: Brasil 500 anos. São Paulo: Editora da Universidade de São Paulo, 2001. p. 53-66.

PEREIRA, Miguel Baptista. Modernidade e secularização. Coimbra: Almedina, 1990. 
ROMANO, Roberto. Moral e ciência: a monstruosidade no século XVIII. São Paulo: Senac, 2003.

SANCHES, A. N. Ribeiro. Cartas sobre a educação da mocidade. Porto: Editorial Domingos Barreira, [s.d.].

SARAIVA, José Hermano. Breve história de Portugal. 3. ed. Lisboa: Bertrand, 1989.

SAVIANI, Dermerval. História das idéias pedagógicas no Brasil. 2. ed. Campinas: Autores Associados, 2008.

SERRÃO, José Vicente. Sistema político e funcionamento institucional no pombalismo. In: MARQUES DA COSTA, Fernando; DOMINGUES, Francisco Contente; MONTEIRO, Nuno Gonçalves (Orgs.). Do Antigo Regime ao Liberalismo (1750-1850). Lisboa: Vega, 1989. p. 11-21.

STEPHANOU, Maria; BASTOS, Maria Helena Câmara (Orgs.). Histórias e memórias da educação no Brasil - v. 1, p. 146-157, séculos XVI-XVIII. Petrópolis: Vozes, 2004.

VERNEY, Luís António. Verdadeiro método de estudar. 3. ed. Porto: Editorial Domingos Barreira, [s.d.].

WEBER, Max. A ética protestante e o espírito do capitalismo. 15. ed. São Paulo: Pioneira, 2000.
CARLOTA BOTO, doutora em história social pela Faculdade de Filosofia, Letras e Ciências Humanas da Universidade de São Paulo (FFLCH-USP), é professora da Faculdade de Educação na mesma instituição. É bolsista produtividade do CNPq. Publicações importantes: A escola do homem novo: entre o Iluminismo e a Revolução Francesa (São Paulo: Editora da Universidade Estadual Paulista, 1996); O enciclopedismo de Ribeiro Sanches: pedagogia e medicina na confecção do Estado (História da Educação. FaE/ UFPel, v.2, n. 4., p. 107-117, set. 1998); Iluminismo e educação em Portugal: o legado do século XVIII ao XIX (In: STEPHANOU, Maria \& BASTOS, Maria Helena Câmara (Orgs.). Histórias e memórias da educação no Brasil. Volume 1: séculos XVI-XVIII. Petrópolis: Vozes, 2004. p. 158-178); Reforma pombalina - 28 de junho de 1759 (In: BITTENCOURT, Circe. Dicionário de datas da História do Brasil. São Paulo: Contexto, 2007). Pesquisa em andamento: "A escola da Revolução Francesa: política e pedagogia na agenda pública”.E-mail: reisboto@usp.br

Recebido em julho de 2009 Aprovado em novembro de 2009 
Isabel Cristina Alves da Silva Frade

Uma genealogia dos impressos para o ensino da escrita no Brasil no século XIX

O objetivo deste artigo é caracterizar e compreender diferentes modelos e formatos de livros escolares ou de outros impressos para ensinar os princípios da escrita, utilizados na Província de Minas Gerais e no Brasil a partir do início do século XIX. Anterior a uma produção escolar mais autoral de livros para ensinar a ler, encontramos menções sobre o uso de abecedários, cartas do ABC e silabários. Na ausência de materiais conservados, buscaram-se indícios de como eles se apresentavam e eram utilizados em fontes primárias (correspondências, relatórios, mapas de desempenho) produzidas na Província de Minas Gerais, desde 1823. Com essas fontes, problematizamos o uso de tabelas, tábuas e cartas. Outro conjunto de fontes analisado é constituído por quatro livros brasileiros e um livro traduzido para o português, cujos títulos continham as denominações silabário, abecedário e cartas de ABC. A investigação baseia-se não só nos campos da história da leitura e do livro (Roger Chartier), que abordam as formas dos textos, dos impressos e de seus usos, mas também nos estudos da história da alfabetização e da educação, no mesmo período. Para uma análise comparativa, fontes secundárias francesas ajudam a compreender a forma e os usos de tabelas, abecedários e silabários.

Palavras-chave: impressos, tábuas, tabelas, cartas de ABC, silabários, abecedários, história da alfabetização, cultura escrita, escolarização da escrita.

\section{A genealogy of printed material for teaching writing in Brazil in the nineteenth century \\ The aim of this article is to characterize and understand the different models and formats of textbooks or other printed material for teaching the basics}

of writing, used in the Province of Minas Gerais and in Brazil, from the early nineteenth century. Before the production of more authorial books to teach reading at school, we find mention of the use of literacy primers, $A B C$ letters and first reading books. In the absence of well preserved materials, we searched for evidence of how they were presented and used, in primary sources (correspondence, reports, performance charts) produced in the Province of Minas Gerais since 1823. With these sources the use of tables, boards and letters was problematised. Another set of sources examined is composed of four Brazilian textbooks and a book translated into Portuguese, whose titles contained such denominations as first reading book, literacy primers and ABC letters. The research is based not only on studies related to the history of books and reading (Roger Chartier), which deal with the types of text, printed matter and their uses but also to studies on the history of literacy education in the same period. For a comparative analysis, French secondary sources help to understand the form and uses of tables, literacy primers and first reading books.

Key words: printed material, boards, tables, ABC letters, first reading books, literacy primers, history of literacy, written culture, school taught writing

Una genealogía de los impresos para la enseñanza de la escrita en Brasil en el siglo XIX

El objetivo de este artículo es caracterizar y comprender diferentes modelos y formas de libros escolares o de otros impresos para enseñar los principios de la escritura, utilizados en la Provincia de Minas Gerais y en Brasil a partir del inicio del siglo XIX. Anterior a una producción escolar más autoral de libros para enseñar a leer, encontramos menciones sobre el uso de abecedarios, cartas de $A B C$ y silabarios. En la falta de materiales conservados, se buscaron indicios de cómo ellos se presentaban $y$ eran utilizados, en fuentes primarias (correspondencias, velatorios, mapas de desempeño) producidas en la Provincia de Minas Gerais, desde 1823. Con estas fuentes, se problematiza el uso de tablas y cartas. Otro conjunto de fuentes analizado es constituido por cuatro libros brasileños y un libro traducido para el portugués, cuyos titulos contenian las denominaciones silabario, abecedario y cartas de $A B C$. La investigación se fundamenta no sólo en los campos de la historia de la lectura y del libro (Roger Chartier), que abordan las formas de los textos, de los impresos y de sus usos, como también en los estudios de la historia de la alfabetización y de la educación, en el mismo periodo. Para un análisis comparativo, fuentes secundarias francesas ayudan a comprender la forma $y$ los usos de tablas, abecedarios y silabarios.

Palabras clave: impresos, tablas, cartas de ABC, silabarios, abecedarios, historia de la alfabetización, cultura escrita, escolarización de la escritura.

Carlota Boto

\section{A dimensão iluminista da reforma pombalina dos estudos: das} primeiras letras à universidade O presente artigo tem por propósito discutir o tema da educação à luz da intersecção entre os ideais políticos e pedagógicos de três pensadores iluministas portugueses - Dom Luís da Cunha, António Nunes Ribeiro Sanches e Luiz António Verney - e a reforma dos estudos empreendida pelo Marquês de Pombal. A ação de Pombal como ministro do reino português foi, em certa medida, embasada por reflexões teóricas acerca de Portugal e da crise do império português. Essas reflexões, entre outros aspectos, destacavam ser uma necessidade histórica para o desenvolvimento do país o Estado português tomar para si o controle das questões do ensino em todos os seus níveis. Ao expulsar os jesuítas, ao 
idealizar o modelo das aulas-régias, mas, sobretudo, ao reformar os estudos da Universidade de Coimbra, a prática da ação pombalina indicava sua filiação teórica ao movimento iluminista português.

Palavras-chave: instrução pública; Portugal; história da educação; Marquês de Pombal; Iluminismo.

\section{The illuminist dimension of the} Pombaline reform of studies: from literacy to the university

The objective of this article is to discuss the theme of education in the light of the intersection between the political and pedagogic ideals of three Portuguese Enlightenment thinkers Dom Luis da Cunha, Antonio Nunes Ribeiro Sanches and Luiz Antonio Verney - and the educational reform carried out by the Marquis of Pombal. The action of Pombal as minister of the Portuguese kingdom was to some degree based on theoretical reflections on Portugal and the crisis of the Portuguese empire. Such reflections, among other aspects, emphasized that, for the country to develop, the Portuguese government was historically bound to take control of teaching issues at all levels. By expelling the Jesuits, idealizing the model of the regal-classes, but, above all, by reforming the studies of the University of Coimbra, the practice of Pombal's action indicated its theoretical affiliation with the Portuguese Enlightenment movement.

Key words: public education; Portugal, history of education; Marquis of Pombal; Enlightenment

\section{La dimensión iluminista de} la reforma pombalina de los estudios: de las primeras letras a la universidad

Este artículo tiene como propósito discutir el tema de la educación a la luz de la intersección entre los ideales politicos y pedagógicos de tres pensadores iluministas portugueses

- Don Luis da Cunha, António Nunes
Ribeiro Sanches y Luiz António Verney - y la reforma de los estudios emprendida por el Marqués de Pombal.

La acción de Pombal como ministro del reino de Portugal fue, en cierta medida, sustentada por reflexiones teóricas acerca de Portugal y de la crisis del imperio portugués. Tales reflexiones, entre otros aspectos, destacaban que era una necesidad histórica para el desarrollo del país, el Estado portugués tomó para sí el control de las cuestiones de la enseñanza en todos sus niveles. Al expulsar los jesuitas, al idealizar el modelo da las clases regias, mas, sobretodo, al reformar los estudios de la Universidad de Coimbra, la práctica de la acción pombalina indicaba su filiación teórica al movimiento iluminista portugués.

Palabras clave: instrucción pública; Portugal; historia de la educación; Marqués de Pombal; Iluminismo

Danilo R. Streck

Entre emancipação e regulação: (des) encontros entre educação popular $\mathrm{e}$ movimentos sociais

$\mathrm{O}$ artigo analisa a dupla face da educação popular na sua relação com os movimentos sociais na América Latina, como subsidiária e promotora destes. Por um lado, pode-se dizer que a educação popular é a expressão pedagógica dos movimentos e como tal é aliada na conquista de direitos políticos e civis. Ao mesmo tempo, enquanto processo pedagógico, ela é também uma instância formadora e orientadora da sociedade e dos próprios movimentos sociais. Analisam-se as mudanças nas relações entre a educação popular e os movimentos sociais especialmente a partir da década de 1990, quando entram em cena novas forma de regulação e controle. São destacados dois temas neste estudo: os territórios de resistência e as respectivas pedagogias, e a questão da nova governabilidade e as implicações para a educação popular.
Palavras-chave: educação popular; movimentos sociais; Paulo Freire; América Latina

Between emancipation and regulation: (mis)matches between popular education and social movements

The article analyzes the double face of popular education in its relation with social movements in Latin America, functioning both as subsidiary and as their promoter. In this sense, one can say that popular education is the pedagogical expression of social movements and, as such, is an ally in the struggle for political and civil rights. At the same time, popular education, as a pedagogical process, fulfils a formative and directive role within society and for the very social movements. In this article, emphasis is placed on analysis of the changes in the relation between popular education and social movements, especially after 1990, when new forms of regulation and control are developed. Two related themes are highlighted in this study: the territories of resistance and their respective pedagogies, and the quest for new forms of governance and their implications for popular education.

Key words: popular education; social movements; Paulo Freire; Latin

America

Entre emancipación y regulación: (des)encuentros entre la educación popular y movimientos sociales Este artículo analiza la faz dupla de la educación popular en su relación con los movimientos sociales en América Latina, como subsidiaria y promotora de estos. Por un lado, se puede decir que la educación popular es la expresión pedagógica de los movimientos y como tal está aliada en la conquista de los derechos politicos y civiles. Al mismo tiempo, como proceso pedagógico, ella es también una instancia formadora y orientadora de la sociedad y de los propios movimientos sociales. Se estudian las 